\title{
BIODIVERSITY ASSESSMENT OF BENTHIC MACROINVERTEBRATES IN ALTITUDINAL LOTIC ECOSYSTEMS OF SERRA DO CIPÓ (MG, BRAZIL)
}

\author{
GALDEAN, N., ${ }^{1}$ CALLISTO, M. ${ }^{2}$ and BARBOSA, F. A. R. ${ }^{2}$ \\ ${ }^{1}$ The National Museum of Natural History "Grigore Antipa”, Kiseleff 1, 79744 Bucharesti, Romania \\ ${ }^{2}$ Laboratório de Limnologia/Ecologia de Bentos, Departamento de Biologia Geral, Universidade Federal de Minas \\ Gerais, ICB, C.P. 486, CEP 30161-970, Belo Horizonte, MG, Brazil \\ Correspondence to: Marcos Callisto, Laboratório de Limnologia/Ecologia de Bentos, Departamento de Biologia \\ Geral, Universidade Federal de Minas Gerais, ICB, C.P. 486, CEP 30161-970, Belo Horizonte, MG, Brazil, \\ e-mail: callisto@mono.icb.ufmg.br \\ Received January 3, 2000 - Accepted March 3, 2000 - Distributed May 31, 2001
}

(With 2 figures)

\begin{abstract}
Five lotic systems of Serra do Cipó, south-east Brazil, were investigated in order to assess the existing diversity of benthic macroinvertebrates, habitats-microhabitats, and the available trophic resources. For each river it was analysed the communities of benthic macroinvertebrates and the composition of some taxonomic groups (Plecoptera, Ephemeroptera, Trichoptera and Diptera Chironomidae): the community with Bivalvia Sphaeriidae, Oligochaeta and Ephemeroptera Baetidae (being supposed a closed relation Bivalvia-Oligochaeta based on the process of bioturbation and enrichment of sediment in organic matter) in Tanque River; the macrofauna associated to aquatic macrophytes from rivers Peixe and Preto do Itambé reflecting the reaction of the ecosystems versus the quantities of nutrients which originate from the farmlands; the lithoreophilic communities of Cipó River; the community depending on deposits of leaves and filamentous algae in Congonhas Stream; the very rich community of the moss clumps in the Indaiá Stream. A proposal for biological zonation of Cipó River and some comments about the importance of the analysed benthic macroinvertebrates in the biological production of the aquatic communities were done.
\end{abstract}

Key words: macroinvertebrates, river ecology, Ephemeroptera, Trichoptera, Chironomidae.

\section{RESUMO \\ Avaliação da biodiversidade de macroinvertebrados bentônicos em ecossistemas lóticos de altitude na Serra do Cipó (MG, Brasil)}

Foram estudados cinco rios na Serra do Cipó, sudeste do Brasil, com o objetivo de avaliar a diversidade de macroinvertebrados bentônicos, os habitats-microhabitats e os recursos tróficos disponíveis. Em cada rio foi estudada a comunidade de macroinvertebrados bentônicos e a composição de alguns grupos taxonômicos (Plecoptera, Ephemeroptera, Trichoptera e Diptera Chironomidae). Foram encontrados padrões de estrutura de comunidades formados por: rio Tanque - Bivalvia, Sphaeriidae, Oligochaeta e Ephemeroptera Baetidae (sugerindo uma relação entre Bivalvia e Oligochaeta no processo de bioturbação e enriquecimento do sedimento quanto ao conteúdo de matéria orgânica); rios Peixe e Preto do Itambé - macrofauna associada a macrófitas aquáticas, refletindo a reação do ecossistema versus a quantidade de nutrientes oriundos das fazendas nas áreas de entorno; rio Cipó - comunidades litoreofílicas; córrego Congonhas - comunidade dependente de depósitos de folhas e algas filamentosas; córrego Indaiá - elevada biodiversidade de macroinvertebrados associados a musgos. Foi formulada uma proposta de zonação biológica no rio Cipó, além de comentários acerca da importância dos macroinvertebrados bentônicos na produção biológica das comunidades aquáticas.

Palavras-chave: macroinvertebrados, ecologia de rios, Ephemeroptera, Trichoptera, Chironomidae. 


\section{INTRODUCTION}

In river ecology the benthic macroinvertebrates community is of paramount importance for the understanding of the structure and functioning of these ecosystems (Cummins, 1992), particularly considering its wide distribution and resiliency. Furthermore, as pointed out by Rosenberg \& Resh (1993) this community also provides an important tool for monitoring and management programs since benthic macroinvertebrates are normally involved within the major processes including a significant role in the energy fluxes and nutrient cycling (Allan, 1996).

In the State of Minas Gerais there are 15 watersheds among which many rivers are important not only for basic purposes such as water supplying, agriculture and industries, also representing important aquatic resources for other uses such as transportation, recreation and wildlife maintenance. Serra do Cipó is an important source of high quality waters. The sustainable development of the area is directly connected with a better understanding of the quantities and quality of the natural aquatic resources and existing aquatic biodiversity. The assessment of benthic communities and habitat diversity offers a chance to evaluate the present level of impacts on the area, which was previously proposed as possessing waters of "reference standards" (Barbosa et al., in press).

The main objectives of this study were to inventory the aquatic habitats, along with estimations of the available trophic resources mainly related to benthic macroinvertebrates in five lotic systems of Serra do Cipó. The recorded trophic resources were discussed as determinant factors for the structure and stability of the present benthic macroinvertebrate communities. Complementary an analysis of the possible strategies of these ecosystems in preserving their functionality was also intended.

\section{STUDY AREA}

Serra do Cipó is located between the coordinates $43^{\circ}-44^{\circ} \mathrm{W}, 19^{\circ}-20^{\circ} \mathrm{S}$ (Fig. 1), comprises several small rivers draining to either São Francisco or Rio Doce watersheds, mostly permanent ones although several temporarily creecks and ponds are also present. The rivers have stony or sandy beds with clear or black waters ranging from acidic (e.g. pH 3.8, Indaiá Stream) to sligtly alkaline (e.g. pH
8.8, Cipó River), of low conductivity (4.3-25.0 $\mu \mathrm{S} /$ $\mathrm{cm}$, except Cipó River with values up to $82.1 \mu \mathrm{S} /$ $\mathrm{cm})$, well oxygenated (70\%-134\% saturation) and levels of total $\mathrm{N}$ and total $\mathrm{P}$ ranging between 6-300 $\mu \mathrm{g} / \mathrm{L}$ and 7-54 $\mu \mathrm{g} / \mathrm{L}$, respectively. The sandy soils are acidic, nutrient-poor and highly subjected to erosion (Freitas \& Silveira, 1977). Quartzitic outcrops are very common, and in their crevisses a more humic soil is found (Freitas \& Silveira, op. cit.). The local climate is classified as Cwb (Köppen), with rainy summers and dry winters, and an average annual rainfall of 1,500 mm (Galvão \& Nimer, 1965).

The area supports a shrubby vegetation or open grasslands (Rizzini, 1979). At altitudes up to $1,000 \mathrm{~m}$ the dominant vegetation is "cerrado", covering an area particularly rich in endemic species (Giulietti, 1996), and the higher hills are covered by this shrubby vegetation locally called "campos rupestres". The botanical diversity of the area is estimated in 1,590 plant species from which c 30\% are endemic (Giulietti et al., 1987).

\section{MATERIAL AND METHODS}

Sediment samples were collected using Kicking nets $\left(1 \mathrm{~m}^{2}\right)$ with $125 \mu \mathrm{m}$ mesh on different types of substrata were collected from the rivers Cipó, Preto do Itambé, Peixe, Tanque and streams Congonhas and Indaiá. The water temperature, $\mathrm{pH}$, dissolved oxygen and electrical conductivity were measured in situ using a multiproble Hydrolab. Total alkalinity was estimated through the Gran method, according to Carmouze (1994) and the velocity of the current was estimated according to Allan (1996).

A total of nine sampling zones during the rainy season (February 1997) and ten sampling zones during the dry season (April and October 1997) were defined based mainly on the type of substrate found. Table 1 summarizes these substrate types.

The samples were fixed with formaline $10 \%$. In the laboratory, after sieving through a $125 \mu \mathrm{m}$ the material was examined under a stereomicroscope, and the organisms are preserved in alcohol $70 \%$ in the reference Collection of Benthic Macroinvertebrates of ICB/UFMG, according with Callisto et al. (1998).

For each taxonomic group (Plecoptera, Ephemeroptera, Trichoptera and Diptera, Chironomidae) it was considered the trophic necessities (based on laboratory analyses, field observations and litera- 
ture - Wiederholm, 1983; Merritt \& Cummins, 1988; Epler, 1995; Pescador, 1997), and also taken into consideration their taxonomic composition, dominance and richness of genera. Bivalvia, Crustacea, Megaloptera, Heteroptera, Coleoptera and Lepidoptera were also considered in the present analysis.

\section{RESULTS}

\section{Tanque River}

This river shows a clayed bed with sand and stony surfaces and zones with coarse gravel and sand (Station 1). A large community of BivalviaSphaeriidae (> $300 \mathrm{ind} / \mathrm{m}^{2}$ ), associated with Oligochaeta (> $250 \mathrm{ind} / \mathrm{m}^{2}$ ), mayflies larvae (90-100 ind/ $\mathrm{m}^{2}$ ) is present on top of the clay bed, while on top of the gravel/sand areas there were mainly Chironomidae, Coleoptera and few specimens of Ephemeroptera and Trichoptera (Table 2).
Furthermore, in zones where the riparian vegetation is permanently washed out there are deposits of clay and fine detritus with Ephemeroptera (Baetidae, Leptophlebiidae, and Tricorythidae), Odonata, Coleoptera, Heteroptera, Trichoptera (mainly Leptoceridae), Chironomidae (Tanytarsini, Tanypus, Djalmabatista, Ablabesmyia, Larsia and Corynoneura).

At the locality of Ipoema (Station 20) there is a tipical lithorheophilic habitat, with boulders, gravel, and sand covering the river bed.

The diversity of benthic macroinvertebrates in this area is significantly high, especially with Ephemeroptera and Trichoptera, followed by Plecoptera, Megaloptera, Coleoptera, Heteroptera, and Diptera-Chironomidae (Cricotopus, $\mathrm{Na}$ nocladius, Polypedilum, Rheotanytarsus and Larsia).

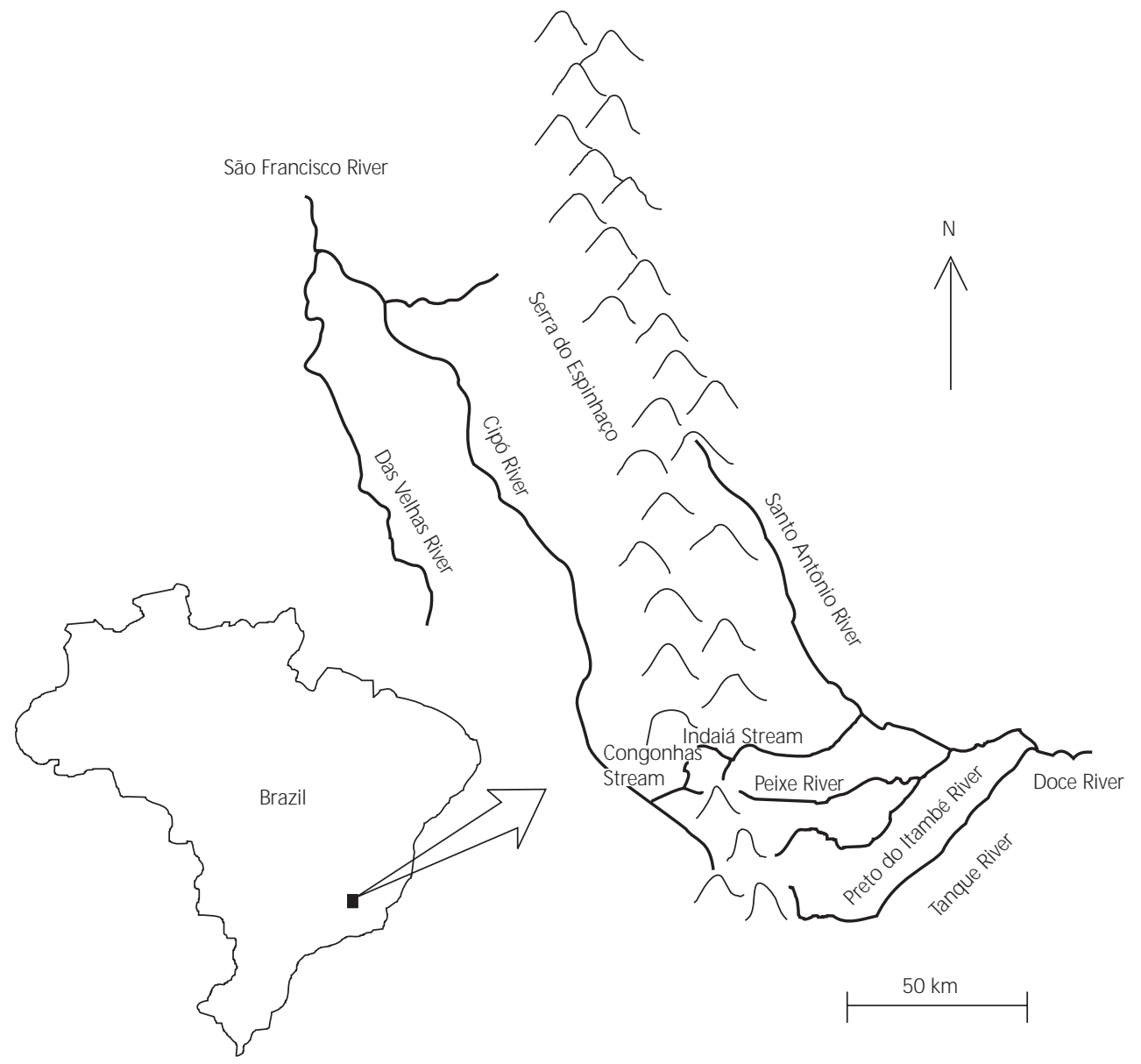

Fig. 1 - Map of the studied area. 
TABLE 1

Characteristic substrata for the investigated area.

\begin{tabular}{|c|c|c|c|c|c|c|c|c|c|}
\hline \multirow[t]{2}{*}{ Rivers and sampling areas } & \multicolumn{9}{|c|}{ Type of substratum } \\
\hline & $\begin{array}{c}\text { Clay + } \\
\text { sand }\end{array}$ & Sand & Gravel & Boulders & $\begin{array}{c}\text { Aquatic } \\
\text { macro- } \\
\text { phytes }\end{array}$ & $\begin{array}{c}\text { Border } \\
\text { vegeta- } \\
\text { tion }\end{array}$ & Moss & $\begin{array}{l}\text { Detritic } \\
\text { deposits }\end{array}$ & $\begin{array}{c}\text { Stones } \\
\text { with } \\
\text { detritus } \\
\text { and } \\
\text { mud }\end{array}$ \\
\hline Tanque $(\# 1,20)$ & * & & * & * & & & & & \\
\hline Peixe $(\# 2,5,16,18)$ & & * & * & * & * & * & & & \\
\hline Preto do Itambé $(\# 3,4,17,19)$ & & * & * & * & * & * & & & \\
\hline Congonhas $(\# 6,14)$ & & & & $*$ & & & $*$ & $*$ & \\
\hline Indaiá $(\# 7,15)$ & & & * & & & & * & & \\
\hline Cipó (\#9, 10, 11, 12, 13) & & & $*$ & $*$ & & & & & * \\
\hline
\end{tabular}

\section{Peixe River}

The river flows mainly on gravel and sand beds although stony areas were also identified. Although normally poor (only some Oligochaeta and Chironomidae have been found) the sandy bottom showed an interesting community amongst the riparian vegetation, which basically depends on the available detritus. There are however some stony areas (boulders and gravel) which also contains some small "islands" of aquatic macrophytes (Station 5). At this habitat the most important fauna is the one associated with the aquatic macrophytes (phytophillous fauna), mainly formed by Ephemeroptera-Baetidae (Baetis, Camelobaetidius, Cloeodes), Leptophlebiidae (Hagenulopsis, Homothraulus, Hermanella) and Tricorythidae (Coryphorus, Leptophyphes); Plecoptera-Perlidae; Coleoptera-Psephenidae and Elmidae; TrichopteraHydropsychidae, Polycentropodidae (Polycentropus), Odontoceridae (Marilia), Glossossomatidae, Helicopsychidae (Helicopsyche), Odonata, Heteroptera, Megaloptera, Lepidoptera, and DipteraChironomidae (the richest comparing with all other samples), Simuliidae and Ceratopogonidae, Turbelaria, and Oligochaeta.

\section{Preto do Itambé River}

At this river it was found similar conditions as in Peixe River (Stations 3 and 17), with the presence of sandy beds (mostly coarse sand) and some stony zones covered with a layer of very fine mud, also existing boulders, mainly in the small waterfalls, riparian vegetation and zones with aquatic macrophytes. An alternation of habitats was found between these two rivers although the sandy bottom is the dominant habitat.

In comparison with Tanque River it is worth to mention the differences in the Baetidae populations in the same type of habitats. So, while in zones with riparian vegetation in Tanque River the mayflies of the genus Baetis were dominant, in similar areas at Peixe River larvae of Cloeodes were dominant.

Our understanding is that although the two mentioned habitats seem to be macroscopically similar, they show differences in specific components thus allowing the onset of different strategies in order to maintaining their functionality.

\section{Cipó River}

This was the most complex lotic system of the investigated area particularly from the point of view of the biological zones as well as considering the direct and indirect anthropogenic influences it is under of.

The upper part of this river shows a sandy bottom possessing a poor benthic fauna. A bit far downstream, near the locality of Cardeal Mota, the river bed is basically a stony one, where the rocks are widely covered with a thin layer of filamentous algae and downwards the presence of boulders and gravel is the dominat river bed, alterning with small zones with coarse sand.

In relation to the benthic macroinvertebrates recorded in this river, five biological zones were identified, as follow: 
TABLE 2

The recorded taxa of benthic macroinvertebrates in Serra do Cipó, MG (* rare; ** common; *** abundant).

\begin{tabular}{|c|c|c|c|c|c|c|c|c|c|c|c|c|c|c|c|c|c|c|c|}
\hline \multirow{2}{*}{$\begin{array}{c}1 \\
\text { Taxa }\end{array}$} & \multicolumn{2}{|c|}{ Tanque } & \multicolumn{4}{|c|}{ Peixe } & \multicolumn{3}{|c|}{$\begin{array}{l}\text { Preto do } \\
\text { Itambé }\end{array}$} & \multicolumn{3}{|c|}{ Congonhas } & \multicolumn{2}{|c|}{ Indaiá } & \multicolumn{5}{|c|}{ Cipó } \\
\hline & $\# 1$ & $\# \mathbf{2 0}$ & $\# 2$ & $\# 5$ & $\# 16$ & \# 18 & $\# \mathbf{3}$ & $\# 4$ & \# 17 & \# 19 & $\# 6$ & $\# 14$ & $\# 7$ & $\# 15$ & $\# 9$ & \# 10 & $\# 11$ & $\# 12$ & \# 13 \\
\hline Turbelaria & $*$ & & & $*$ & & $* *$ & & & & & & & & $*$ & & & & $*$ & \\
\hline Oligochaeta & $* * *$ & $*$ & $*$ & $*$ & & $*$ & $* *$ & $* *$ & $*$ & $*$ & & $*$ & & & $* *$ & $*$ & $*$ & $*$ & $*$ \\
\hline \multicolumn{20}{|l|}{ Bivalvia } \\
\hline Sphaeriidae & $* * * *$ & & & & $*$ & $*$ & & $*$ & $*$ & $*$ & & & & & & & $*$ & & \\
\hline Unionidae & & & & & & & & & & & & & & & & & $*$ & & \\
\hline \multicolumn{20}{|l|}{ Crustacea } \\
\hline Decapoda & & & & & & & & & & & & & & & & $*$ & & $*$ & \\
\hline \multicolumn{20}{|l|}{ Plecoptera } \\
\hline Perlidae & & $*$ & & & $*$ & $*$ & $*$ & $*$ & & $*$ & $*$ & $*$ & $*$ & & & $*$ & $*$ & $* *$ & \\
\hline Gripopterygidae & & & & & & & & & & $*$ & & & $*$ & $*$ & & & & & \\
\hline \multicolumn{20}{|l|}{ Ephemeroptera } \\
\hline \multicolumn{20}{|l|}{ Oligoneuriidae } \\
\hline \multicolumn{20}{|l|}{ Spaniophlebia } \\
\hline \multicolumn{20}{|l|}{ Baetidae } \\
\hline Baetis & $* * * *$ & $* * *$ & $*$ & $* *$ & $* * *$ & $* * *$ & $*$ & $*$ & $* *$ & $* * * *$ & $* *$ & $* *$ & $* *$ & $* *$ & & $*$ & $* *$ & $*$ & $*$ \\
\hline Baetodes & & & & & & & & & & & $*$ & $* *$ & $*$ & $*$ & & $*$ & & $*$ & \\
\hline \multicolumn{20}{|l|}{ Camelobaetidius } \\
\hline Cloeodes & & $*$ & $* * *$ & $* * *$ & & & $* *$ & $* *$ & & & $* *$ & & $*$ & & & & & & \\
\hline \multicolumn{20}{|l|}{ Leptophlebiidae } \\
\hline gr. Farrodes & $*$ & $* *$ & $* *$ & $* *$ & $*$ & ***** & $* *$ & $* *$ & $*$ & $* *$ & $*$ & $*$ & $*$ & $*$ & $*$ & $* *$ & $* * *$ & $* * *$ & \\
\hline gr. Hermanella & & & & & & $*$ & & & & $*$ & & & $* *$ & $* *$ & & $*$ & & $*$ & \\
\hline Trichorithidae & $*$ & $* *$ & $*$ & $* *$ & $*$ & $* * *$ & $*$ & $*$ & $*$ & $*$ & $*$ & $*$ & $*$ & $*$ & & $*$ & $*$ & $* *$ & \\
\hline Polymitarcidae & & & & & & & $*$ & & $*$ & & & & & & & & & & \\
\hline \multicolumn{20}{|l|}{ Heteroptera } \\
\hline Naucoridae & $*$ & $*$ & $* *$ & $* *$ & $*$ & $*$ & $* *$ & $* *$ & $*$ & $* *$ & $* *$ & $*$ & $*$ & $*$ & $*$ & $*$ & $*$ & $*$ & \\
\hline Megaloptera & & $*$ & & $*$ & & $*$ & & & $*$ & $*$ & $*$ & & $* *$ & $* *$ & $*$ & $*$ & & & \\
\hline \multicolumn{20}{|l|}{ Trichoptera } \\
\hline \multicolumn{20}{|l|}{ Calamoceratidae } \\
\hline Phylloicus & & & & & & & & & & & $*$ & $*$ & & & & & & & \\
\hline \multicolumn{20}{|l|}{ Hydropsychidae } \\
\hline Smicridea & $*$ & $* *$ & $*$ & $*$ & & $* *$ & $*$ & & & & & & $* * *$ & $* * *$ & $* *$ & $* * *$ & $*$ & $* * *$ & \\
\hline Leptonema & & & $*$ & & & & & & & & & & & & & & & & \\
\hline \multicolumn{20}{|l|}{ Helicopsychidae } \\
\hline Helicopsyche & & $*$ & & $*$ & & $*$ & & $*$ & & & & $*$ & $* *$ & $* *$ & & $* *$ & & & \\
\hline Hydrobiosidae & & & & & & & & & & & & & & & & & & & \\
\hline
\end{tabular}


TABLE 2 (Continued)

\begin{tabular}{|c|c|c|c|c|c|c|c|c|c|c|c|c|c|c|c|c|c|c|c|}
\hline \multirow[b]{2}{*}{ Taxa } & \multicolumn{2}{|c|}{ Tanque } & \multicolumn{4}{|c|}{ Peixe } & \multicolumn{3}{|c|}{$\begin{array}{l}\text { Preto do } \\
\text { Itambé }\end{array}$} & \multicolumn{3}{|c|}{ Congonhas } & \multicolumn{2}{|c|}{ Indaiá } & \multicolumn{5}{|c|}{ Cipó } \\
\hline & $\# 1$ & $\# \mathbf{2 0}$ & \# 2 & $\# 5$ & $\# 16$ & \# 18 & \# 3 & $\# 4$ & \# 17 & \# 19 & $\# 6$ & $\# 14$ & $\# 7$ & $\# 15$ & \# 9 & \# 10 & \# 11 & \# 12 & \# 13 \\
\hline Atopsyche & & $*$ & & & & & & & & & & $* *$ & $*$ & & & & & & \\
\hline \multicolumn{20}{|l|}{ Leptoceridae } \\
\hline Triaenodes & $* * *$ & & $*$ & $*$ & & & $*$ & & & & & & $* * *$ & & $*$ & $*$ & & & \\
\hline Nectopsyche & $* *$ & & $*$ & $*$ & $*$ & & $* *$ & & & $*$ & & $* *$ & & & & $*$ & * & & \\
\hline Grumichella & & & & & & & & & & & & & $* * *$ & $* * *$ & & & & & \\
\hline Oecetis & & & & & & & & & & & & & & & $*$ & & $*$ & & \\
\hline Amphoropsyche & & & & & & & & & & & & & & & & $*$ & & $*$ & \\
\hline \multicolumn{20}{|l|}{ Odontoceridae } \\
\hline Marilia & & & & $* *$ & & $*$ & & & & & & $* *$ & $*$ & $*$ & & & * & & \\
\hline Barypenthus & & & & & & & & & & & $*$ & $*$ & & & & & & & \\
\hline \multicolumn{20}{|l|}{ Philopotamidae } \\
\hline Chimarra & & $* *$ & & & & & & & & & & $*$ & & $*$ & & $*$ & & $* *$ & \\
\hline Wormaldia & & & & & & & & & & & & & & & & $*$ & & $*$ & \\
\hline \multicolumn{20}{|l|}{ Polycentropodidae } \\
\hline Cyrnellus & & & & & & & & & & & & & & & $*$ & & & & \\
\hline Polycentropus & & & & & & & & & & & & & & & & & $*$ & & \\
\hline \multicolumn{20}{|l|}{ Hydroptilidae } \\
\hline Oxyethira & & $*$ & & $* * *$ & $*$ & & & $* *$ & & & $* *$ & $*$ & & & & & & & $*$ \\
\hline Ochrotrichia & & $*$ & & & $*$ & & & & & & & $*$ & $* * *$ & $* *$ & & & & & \\
\hline Hydroptila & & & & & & & & & & & & $*$ & & & & & & & \\
\hline Leucotrichia & & & & & $*$ & & & & & & & & & & & & & & \\
\hline Neotrichia & & & & & & & & & & & & & & & & $*$ & & & \\
\hline Lepidoptera & & & & $*$ & & $*$ & $*$ & $*$ & & & $*$ & $* *$ & $* * *$ & $*$ & & $*$ & & & $*$ \\
\hline \multicolumn{20}{|l|}{ Diptera } \\
\hline Simulidae & & $* * * *$ & $*$ & $*$ & $*$ & $* * *$ & $*$ & $* *$ & $*$ & $* * * *$ & $*$ & $* *$ & $* *$ & $* * *$ & $*$ & $*$ & $* *$ & $*$ & $*$ \\
\hline Chironomidae & $* * *$ & $* * *$ & $* * *$ & $* * *$ & $* * *$ & $* * *$ & $* * *$ & $* * *$ & $* * *$ & $* * *$ & $* * *$ & $* * *$ & $* * *$ & $* * *$ & $* * *$ & $* * *$ & $* * *$ & $* * *$ & $* * *$ \\
\hline
\end{tabular}

Zone 1: at the municipality of Cardeal Mota within the area of the Parque Nacional da Serra do Cipó, particularly poor in benthic macroinvertebrates, maybe as a consequence of the predominance of a sandy river bottom.

Zone 2: located just bellow the town of Cardeal Mota and in which two sub-zones are evident, one with the presence of filamentous algae and which the benthic community is mainly dominated by Ephemeroptera-Baetidae (Baetis and Cloeodes), Trichoptera-Hydroptilidae (Oxyethira), Lepidoptera, and Diptera-Simuliidae; and a second one, near Fazenda Chácara, where the river bottom is mainly formed by boulders, gravel and deposits of fine detritus. At this sub-zone is remarkable the presence of Oligoneuriidae (Ephemeroptera) represented by the genus Spaniophlebia, a very sensible group. Moreover, other Ephemeroptera also occur although in very low numbers, such as Baetidae and Tricorythidae. Higher diversities of Trichoptera: Leptoceridae, Hydropsychidae ( $\mathrm{Smi}$ cridea), Polycentropodidae (Cyrnellus), Hydroptilidae are also present, as well as various Simuliidae, and few specimens of Odonata and Megaloptera.

Zone 3: at the municipality of Santana do Riacho, where the river bottom is formed mainly by boulders and gravel along with deposits of fine and coarse detritus and showing a relatively high diversity of benthic organisms. At this zone there were recorded Ephemeroptera-Leptophlebiidae 
(Farrodes and Hermanella), Tricorythidae, Baetidae (Baetis, Cloeodes, Baetodes and Camelobaetidius), Plecoptera-Perlidae, Trichoptera (mainly Hydropsychidae and Philopotamidae), DipteraSimuliidae and Chironomidae (Tanytarsini, Polypedilum and Ablabesmyia). It must be pointed out the presence of some Crustacea-Decapoda within the deposits of coarse detritus (leaves), organisms belonging to the functional group of shreders, despite the conditions of the habitats seem to be not favorable.

Zone 4: at the municipality of Santana do Pirapama, where the river bottom is formed mainly by boulders and gravel with a layer of algae and moss clumps. The local conditions are specially favorable for Trichoptera-Hydropsychidae (Smicridea), Philopotamidae (Chimarra). The community also contains Ephemeroptera- Leptophlebiidae (Farrodes), Baetidae and Tricorythidae, PlecopteraPerlidae, Odonata, Heteroptera, Coleoptera, Diptera-Chironomidae (Rheotanytarsus, Cricotopus, Thienemanniella) and Ceratopogonidae.

Zone 5: located just before the confluence with the Paraúna River, showing more diversified substrata formed by boulders, gravel, clay, sand, coarse organic detritus (branches and leaves) and, on top of the hard surfaces, the presence of moss clumps, algae and deposits of fine detritus. At this particular microhabitat were found PlecopteraPerlidae, Ephemeroptera-Leptophlebiidae (group Farrodes), Trichorythidae, Trichoptera-Philopotamidae (Chimara), Hydropsychidae (Smicridea and Leptonema), Hydrobiosidae; Heteroptera, Odonata, Lepidoptera, Diptera-Simuliidae and Chironomidae (Cricotopus, Nanocladius).

The surfaces covered by a layer of algae (bioderm) are specially used by Trichoptera-Philopotamidae, Hydropsychidae, Ephemeroptera-Baetidae (Baetis, Baetodes, Camelobaetidius), Tricorythidae and Leptophlebiidae, PlecopteraPerlidae, Odonata, Heteroptera, Coleoptera-Elmidae and Psephenidae, Lepidoptera, Diptera- Simuliidae and Chironomidae (Psectrotanypus and Endochironomus), Oligochaeta, Turbelaria, and Bivalvia.

\section{Congonhas Stream}

This stream posses mainly a stony bottom covered with a layer of filamentous algae, also existing zones with sand and boulders among which there are deposits of coarse detritus (branches and leaves). The benthic community is dominated by
Diptera-Chironomidae (Cricotopus and Thienemanniella), also existing Ephemeroptera-Baetidae (Baetis, Baetodes and Camelobaetidius), Trichoptera (Calamoceratidae, Philopotamidae, Odontoceridae, Hydroptilidae and Hydrobiosidae), ColeopteraPsephenidae and Lepidoptera.

\section{Indaiá Stream}

This is a very particular environment exhibiting basically a stony river bed mostly covered with mosses and supporting a rich community of benthic organisms composed by Turbelaria, Oligochaeta, Plecoptera Gripopterygidae, Ephemeroptera-Baetidae (Baetis, Baetodes, Camelobaetidius), Leptophlebiidae (Hermanella, Hylister), Tricorythidae), Heteroptera, Megaloptera, Coleoptera Elmidae, Trichoptera-Hydropsychidae, Hydroptilidae (Ochrotrichia), Helicopsychidae (Helicopsyche), Leptoceridae (Grumichella), Odontoceridae (Marilia), Philopotamidae, Lepidoptera, DipteraSimuliidae and Chironomidae (Tanytarsini, Thienemanniella, Beardius, Corynoneura).

It was found the abundance of filtering collectors and the presence of larvae of Megaloptera which are the main predators in this environment.

The waters are similar with Congonhas, of excellent quality (7-9 mg/L dissolved oxygen, < 15 $\mu \mathrm{S} / \mathrm{cm}$ electrical conductivity, $<10 \mathrm{mEq} / 1 \mathrm{CO}_{2}$, $<$ $20 \mu \mathrm{g} / \mathrm{L}$ total $\mathrm{P}$ and $<250 \mu \mathrm{g} / \mathrm{L}$ total $\mathrm{N}$ ), and possessing a rich and diversified benthic fauna. These streams are located within the area of the Parque Nacional da Serra do Cipó, thus no under any human influence, close to the pristine conditions.

Despite the apparently similar general aspects, these two streams show significant differences concerning their benthic macroinvertebrates communities. Congonhas stream is mainly dominated by Chironomidae larvae (Cricotopus), also existing many Baetidae (Baetis, Baetodes, Camelobaetidius, Cloeodes) and Tricorythidae larvae and few Leptophlebiidae. Trichoptera are not very diverse and showing low densities (Cochliopsyche, Helicopsychidae). On the other hand, the stream Indaiá seems to posses a higher equitability in the distribution of the benthic groups thus exibiting a better qualitative structure, exemplified by a better diversity of Leptophlebiidae and the presence of the genus Hermanella and related genera. The majority of identified groups showed a high abundance of organisms including the presence of two 
important groups of filtering-collectors: Hydropsychidae (Trichoptera) and Simuliidae (Diptera).

Particularly in relation to the structure of the existing communities, it is important to consider the specific trophic resources and their availability within these two streams. In the Congonhas Stream there are some shredders using detrital deposits (Trichoptera Hydroptilidae, Calamoceratidae and Lepidoptera). The larvae of Chironomidae (over 90\% belonging to the genus Cricotopus) are feeding on the filamentous algae. The number of filtering collectors is very low. On the other hand, in the Indaia Stream the compact stratum of mosses represents not only the dwelling place of the benthic macroinvertebrates but also a complex structure which allows for the accumulation of organic particles (fecal pelets, pieces of moss, chitinous detritus, dead algae and protozoa). The flowing waters provides a permanent transport of these particles thus allowing the development of large populations of filtering collectors, mainly Trichoptera and Diptera Simuliidae (Simulium).

In the Indaiá Stream, the compartment of shredders is mainly sustained by Lepidoptera larvae which offers considerable amounts of particulate organic matter to the filtering collectors (Fig. 2).

\section{DISCUSSION}

Particularly two main trophic resources are important at Tanque River: i) the fine particulate organic matter-FPOM, originated mainly from the allochthonous material carried by the runnof and which is accumulated between the leaves and bran- ches of the aquatic macrophytes; and ii) organic particles, of different sizes, adsorbed to the suspended clay spheres and which are recirculated by the microcurrents at the surface of the sediment. Such conditions develop two characteristic communities, one dependent on the border vegetation and another one, amidst the sediments, as follows:

a) the community mainly composed by mayflies (Baetis and Apobaetis), Trichotera Leptoceridae and Diptera Chironomidae;

b) the community formed mainly by Sphaeriidae, Oligochaeta and also mayflies.

A relation between Sphaeriidae/Oligochaeta is supposed to be like the following: the oligochaets have an important bioturbation activity thus ensuring dissolved oxygen for Bivalvia and also suspending the organic particles. On the other hand, the excreta of Bivalvia enrich the sediments with easy to use organic matter by the oligochaets. This community association however was restricted to few sedimentary areas, and in low densities.

According to Hildrew \& Giller (1994) this patched repartition seems to be determined, in general, by the intensity of the flowing water. In the present case however, our assumption is that it is more dependent on the quantity and quality of the available trophic resources. Furthermore, according to the cited authors, this community can be considered a competitive one, more precisely a partitioning competitive community. If this is so, the mollusks and oligochaets are then ecologically differentiated populations, depending basically on each other to using similar resources.

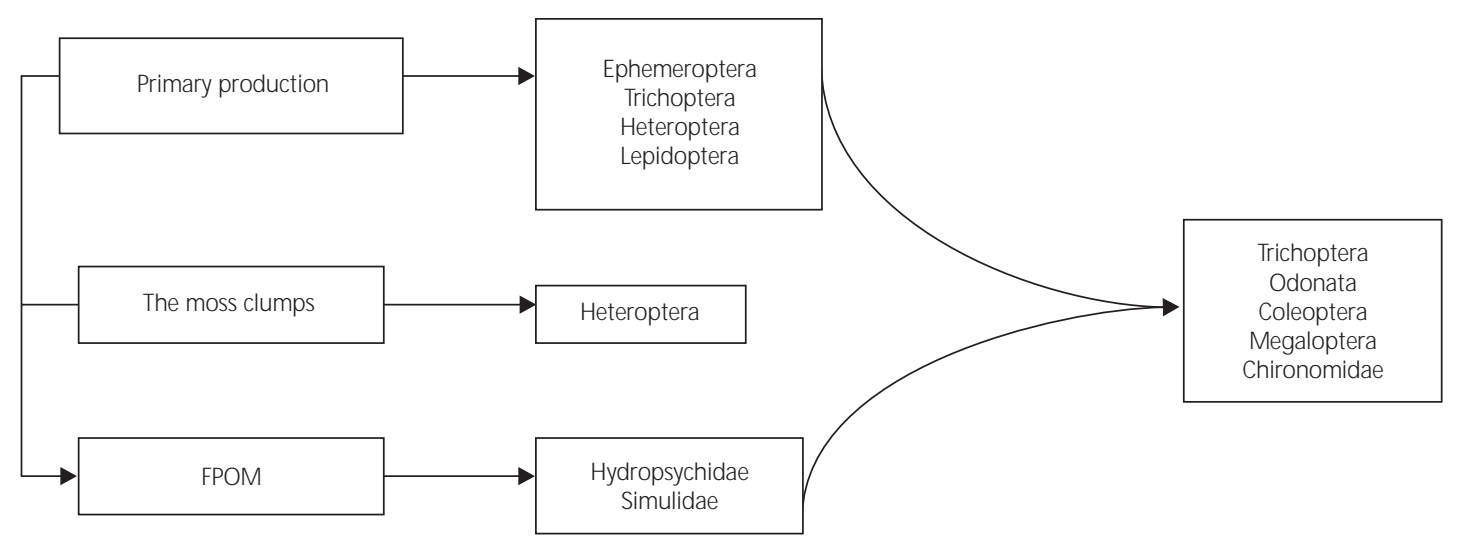

Fig. 2 - A proposed scheme of the benthic community structure found for the Indaiá Stream in 1997. 
In both rivers Peixe and Preto do Itambé probably the fauna associated with aquatic macrophytes has the important function of controlling the quantities of the loaded nutrients originated from farmlands and that are used mainly by the periphytic communities. Furthermore, despite of the many similarities in their structure, the benthic communities use different strategies, as follow:

a) the phytophillous fauna in Peixe River shows higher diversity and thus showing a more stable equilibrium. Ephemeroptera (many Baetidae and some Tricorythidae) is the major group, followed by a relatively high diversity of Trichoptera. The diversity of predators is considerable, there existing Turbelaria, Coleoptera, Odonata, Megaloptera, and Trichoptera Odontoceridae.

b) At the Preto do Itambé River the dominant groups are Ephemeroptera Baetidae and Diptera Simuliidae, with a low diversity of Trichoptera and only Odonata as main predators.

The remarkable alternance of habitats within Cipó River is of a paramount importance in the processing of the organic matter and thus for the available trophic resources. So, most of the autochthonous primary production (algae and mosses) is mainly performed at the stony areas, which offers not only the ideal substrata for these primary producers but also guarantee the necessary light intensity (low depth and turbidity); deposition of coarse and fine detritus is mainly completed within the areas rich in boulders, while the fine particulate organic matter will remain suspended or sedimented in those areas rich in mosses or in between the gravel. Such spatial distribution allows the maintenance of an equilibrium in the distribution between the gathering and filtering collectors.

It was interesting to notice the low density of filtering collectors (Hydropsychidae and Simuliidae) in the last sampling zone, just before the confluence with the Paraúna River. Our understanding is that most of the fine organic particles are mainly sedimenting thus depriving the water of suspended particles essential for this group of organisms. Furthermore, in this last part, the river is flowing through a zone of "Cerrado" which would then contribute with a low amount of allochthonous organic matter to be used by these organisms. On the other hand, the areas rich in mosses support another type of community, dominated mainly by Ephemeroptera, Trichoptera and Chironomidae as found at the Indaiá Stream.

In concluding it seems to us that the key-point in understanding the structure and distribution of benthic macroinvertebrates within Congonhas and Indaiá streams is the presence of moss clumps, which must be understand not only as a substratum but mainly as a basic element which is of paramount importance for the community's trophic structure, a role similar to the exertec by the aquatic macrophytes and its associations.

In relation to the general functioning of the above systems these results also allow for some characterisation of the investigated communities from the point of view of their importance for the general production of the ecosystems. So, in relation to the category of the fine filtering collectors (Simuliidae larvae) the systems are very efficient: the strategy used by the populations is to maintain, at the same time, a low level of polymorphism (at least regarding the dimensions of the individuals), like observed at the Indaiá Stream in April 1997, when most the recorded specimens of Simuliidae were in the last instar, a stage when their filtering capacity was the highest thus taking advantage of their high densities. Moreover, it is worth to mention the absence of fishes thus allowing the highest production of Simuliidae and Hydropsychidae larvae, which can be mainly used by Megaloptera larvae. Macro-filtering collectors (Smicridea and Leptonema, Hydropsychidae) are known to be very productive when the invertebrate drift densities are high (Benke, 1993) an almost permanent situation at this ecosystem. In February, the Hydropsichidae larvae were mainly the big ones in the last instar, while the simuliid larvae were small, a situation just the opposite recorded in April. The small dimensions of the Megaloptera larvae captured in April can be explained as an adaptation of this carnivorous population to its most preferable prey, the hidropsychid larvae. To catch their preys, megaloptera larvae must sprawl between the mosses and the accessibility to the preys depends on their ability and efficiency to find them within this microhabitat, thus being a general assumption that big larvae will search preferably for big preys.

The present results show that Chironomidae and Trichoptera are the most diverse at the generic level. For the Trichoptera, this can be explained by their capacity to use different trophic resources. 
Concerning the existing functional groups these data also allow to conclude that Hydropsychidae are macro filtering-collectors, Philopotamidae are scrapers, Hydroptilidae are grazers and detritivorous, Helicopsychidae are shredders, Odontoceridae particularly the genus Marilia are predators. This diversified benthic community allow them to use either fine and/or coarse detritus as well as fine and/or coarse particulate organic matter, suspended particles, vegetal tissues and algae (perifiton), although mostly they are depending on allochotonous organic matter.

Acknowledgments - The authors thank the Brazilian Research Council (CNPq), Pró-Reitoria de Pesquisa (UFMG) and Fapemig for the financial support.

\section{REFERENCES}

ALLAN, J. D., 1996, Stream ecology: structure and function of running waters. Chapman \& Hall, New York, $388 \mathrm{p}$.

BARBOSA, F. A. R., CALLISTO, M. \& GALDEAN, N. (in press). The diversity of benthic macroinvertebrates as an indicator of water quality and ecosystem health: a case study for Brazil. J. Aquat. Ecos. Health \& Restoration.

BENKE, A. C., 1993, Concepts and patterns of invertebrate production in running waters. Verh. Intenat. Verein. Limnol., 25: 15-38.

CALlisto, M., BARBOSA, F. A. R. \& VIANNA, J. A., 1998, Qual a importância de uma coleção científica de organismos aquáticos em um projeto de biodiversidade? An. IV Simp. Ecos. Brasil., 2: 432-439.

CARMOUZE, J. P., 1994, O metabolismo dos ecossistemas aquáticos: fundamentos teóricos, métodos de estudo e análises químicas. Ed. Edgard Blücher, Fapesp, 253p.

CUMMINS, K. W., 1992, Invertebrates. In: P. Calow \& G. E. Petts. The rivers handbook - hydrological and ecological principles. Blackwell Science Ltd., Oxford, v. 2, 526p.
EPLER, J. H., 1995, Identification manual for the larval Chironomidae (Diptera) of Florida. Revised edition. Depart. of Envir. Protection of Florida, 450p.

FREITAS, F. G. \& SILVEIRA, C. O., 1977, Principais solos sob vegetação de cerrado e sua aptidão agrícola. pp. XXX. In: M. G. Ferri (ed.), IV Simp. sobre o Cerrado Bases para utilização agropecuária. Coleção Reconquista do Brasil, n. 38.

GALVÃO, M. V. \& NIMER, E., 1965, Clima. Geografia do Brasil-Grande Região Leste. IBGE, Rio de Janeiro, 5: 91-139.

GIULIETTI, A. M., 1996, Flora: diversidade, distribuição geográfica e endemismos. In: G. W. Fernandes (ed.), Serra do Cipó: ecologia e evolução. Ed. Vozes, Rio de Janeiro.

GIUliETTI, A. M., MENEZES, N. A., PIRANI, J. R., MEGURO, M. \& VANDERLEY, M. G. L., 1987, Flora da Serra do Cipó: caracterização e lista de espécies. Boletim de Botânica, 9: 1-151.

HILDREW, A. G. \& GILLER, P. S., 1994, Patchiness, species interactions and disturbance in the stream benthos. In: P. S. Giller, A. G. Hildrew \& D. G. Raffaelli (eds.), Aquatic ecology: scale, pattern and process. Blackwell Science, pp. 21-62.

MERRITT, R. W. \& CUMMINS, K. W., 1988, An introduction to the aquatic insects of North America. $2^{\text {nd }}$ edition. Kendall/Hunt, 758p.

PESCADOR, M. L., 1997, General ecology of mayflies: adaptations, reproductive strategies and trophic categories. In: Bioindicadores ambientales de calidad de agua. Universidad del Valle, Colombia.

RIZZINI, C. T., 1979, Tratado de fitogeografia do Brasil. Hucitec, Edusp, São Paulo, v. 2, 374p.

ROSENBERG, D. M. \& RESH, V. H., 1993, Introduction to freshwater biomonitoring and benthic macroinvertebrates. In: D. M. Rosenberg \& V. H. Resh (eds.), Freshwater biomonitoring and benthic macroinvertebrates. Chapman \& Hall, New York, pp. 1-9.

WIEDERHOLM, T. (ed.), 1983, Chironomidae of the Holartic region. keys and diagnoses. Part 1. Larvae. Entomologica Scandinavica 19, 457p. 